\title{
閉栓採血管に対応した微量分注ノズルの開発
}

堀江 陽介 ${ }^{* 1}$, 森 高通 $^{* 2}$

\section{Development of micro sampling nozzle for closed tube}

\author{
Yosuke HORIE $^{* 1}$ and Takamichi MORI ${ }^{* 2}$ \\ ${ }^{* 1}$ Hitachi Ltd., Research \& Development Group \\ 832-2 Horiguchi, Hitachinaka-shi, Ibaraki 312-0034, Japan \\ ${ }^{* 2}$ Hitachi High-Technologies Corporation \\ 882 Ichige, Hitachinaka-shi, Ibaraki 312-8504, Japan
}

Received: 25 December 2016; Revised: 16 February 2017; Accepted: 11 April 2017

\begin{abstract}
In a biochemical automatic analyzer, generally it is necessary to open the cap of the sample tube before the analysis. Users of the analyzer demand a closed tube sampling (CTS) function to reduce the workload and the infection risk. CTS is a sampling method in which the sharp tip of a nozzle goes through the rubber cap of a sample tube and aspirates a part of the liquid in the tube. One of the main challenges of this method is the development of a nozzle that has high durability (requires low insertion load) and produces few rubber chips when inserted through the rubber cap. This paper describes the study of the shape of the nozzle in order to reduce the insertion load and the production of rubber chips. It was found that the parameter that influences the insertion load most is the angle of the taper. Therefore, to reduce the load, it is necessary to reduce the taper angle. By using a nozzle with a tip diameter of $0.8 \mathrm{~mm}$, base diameter of $1.6 \mathrm{~mm}$, and taper length of $20 \mathrm{~mm}$, it was possible to reduce the load required to insert the nozzle through a rubber cap to $34 \mathrm{~N}$. It was also found that the parameter that most influences the production of chips is the cut angle of the nozzle. Rubber chip production could be avoided with the combination of an angle smaller than $28.5^{\circ}$ at the nozzle chip for smooth insertion and an angle larger than $15.0^{\circ}$ at the inside edge for preventing cutting rubber off. Finally, to validate the durability and effectiveness of this shape, the nozzle was subjected to a test in which it was inserted through a rubber plate 50,000 times. Results showed that there was almost no nozzle abrasion nor increase of insertion load, which demonstrates the durability and effectiveness of this new shape.
\end{abstract}

Key words : Medical equipment, Optimum design, Drilling, Cutting, Chip

\section{1. 緒言}

採血した血液から臟器の異常を診断する生化学自動分析装置（左藤，1995）は，装置に投入された採血管内の 血液を一定量取り分ける分注を行い，装置内に保管する試薬と混合することで，その反応過程から各種成分分析 （Farré et al., 1991）を行う. 生化学自動分析装置では, 血液・試薬の分注を行うために液体の吸引・吐出が可能 な細長い中空の金属製ノズルが用いられる，ノズルは，分注機構と呼ばれる多自由度の位置決め機構に取り付け られ，複数のポジションを移動可能である．また，血液を分注後にはノズルの内外を水で洗浄することで，同じ ノズルが繰り返し使用される．生化学自動分析装置は，このような分注動作を高速に行うことで，高スループッ トでの検查を実現している（池田他，2000)。分注機構のような液体ハンドリング技術（Kong et al., 2012）は，生 化学自動分析装置に限らずライフサイエンスの分野で広く活用されている.

血液検査に使われる採血管は，運搬時に内部の液体（血液などのサンプル）が外部に漏れ出ることを防ぐため に，上部をゴムなどでできた蓋で封止している．生化学自動分析装置の多くは，採血管の蓋を外す機構を搭載し ていないため，装置へ投入する前に採血管から蓋を外し検査後に蓋を取り付ける必要がある．蓋を外す機構を搭

No.16-00579 [DOI: 10.1299/transjsme.16-00579], J-STAGE Advance Publication date : 21 April, 2017

*1 正員，(株）日立製作所 研究開発グループ（テ312-0034 茨城県ひたちなか市堀口 832-2）

*2（株）日立ハイテクノロジーズ（†312-8504 茨城県ひたちなか市市毛 882）

E-mail of corresponding author: yosuke.horie.ck@hitachi.com 
載しない理由は, 装置設置スペースやコストの増加である.ゴム栓の取り外し作業は, 作業時間が増えるばかり ではなく, 蓋に付着した血液が飛散し場合によっては感染するリスクもある. そのため, 生化学自動分析装置に は，閉栓採血管から内部のサンプルを直接分注する CTS（Closed Tube Sampling，キャップピアス式サンプリング とも呼ばれる）機能の搭載が望まれている（前川, 濱田，2010）。CTS 機能は, 従来の分注機構に代えて, ゴム 栓を貫通するために先端を鋭利にした CTS ノズルを備えた分注機構を用いるため, 従来装置と比べ設置スペース やコストの大幅な増加にはならない.

図 1 に CTS ノズルを搭載する分注機構（CTS 分注機構）の概略図を示す. CTS 分注機構は, 水平方向（図中 のX方向）之鉛直方向（図中の Z 方向）にCTS ノズルを移動できる. 蓋を外した採血管から吸引する従来の分 注機構は，ノズルを軽量化されたアーム先端に備え，ゴムベルトとプーリでアームを回転してノズルの位置決め を行う。これに対してCTS 分注機構は, ゴム栓貫通時に Z 方向の大きな荷重が加わるため, 従来よりも高剛性化 が必要であり, 各駆動軸にはリニアガイドを備え, 駆動方式はベルト・プーリからボールねじとした. ただし, 過度の高剛性化はコスト面で不利となるため, 本機構は CTS ノズル挿入時の最大荷重が $50 \mathrm{~N}$ 以下となることを 想定して設計を行った. CTS ノズルは, 従来の分注機構と同様に, CTS ノズル基部に装置内にあるシリンジポン プや電磁弁などから構成される流路とチューブで接続される.

図 2 に CTS 分注機構の分注動作フローを示す. CTS 分注機構の動作は, ゴム栓を貫通する部分以外は従来の分 注機構と同じで, ノズル洗浄, サンプル吸引, サンプル吐出の流れで分注を行う. CTS ノズルは繰り返し分注に 使用するため, 毎回ノズル洗浄を行う. 洗浄では, サンプルと接触したノズル先端部の外周を水流で洗い流し, ノズル内はポンプの送液で洗浄する.

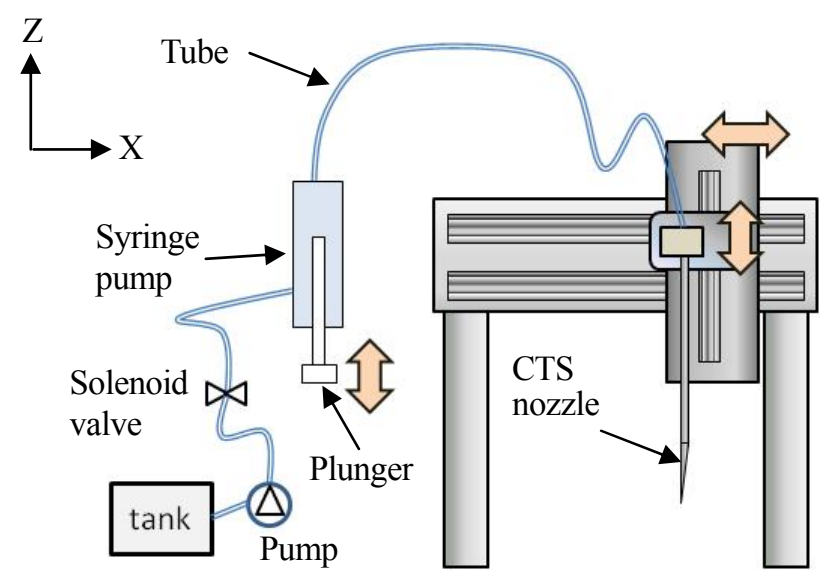

Fig. 1 Mechanism of CTS pipetter.

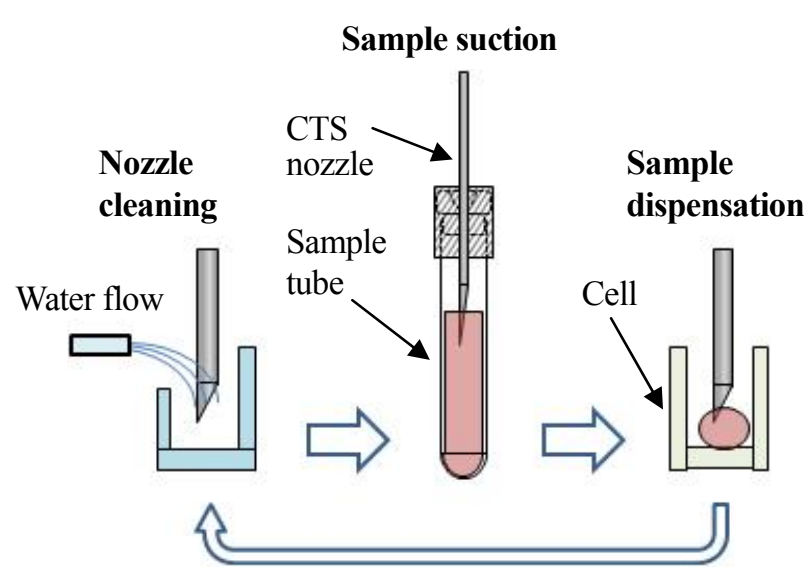

Fig. 2 Flow of pipetting motion. CTS nozzle is washed and reused.

CTS 技術における主な開発項目は，（1）CTS ノズルと（2）サンプル吸引である. サンプル吸引は，ゴム栓で 密封され内部が真空となった採血管からサンプルを吸引するため, 採血管内の負圧によって従来の分注とは異な る液の挙動を示寸点が従来と異なる，そのため，負圧の影響をなくすため，採血管内の負圧を開放する方法（穴 見，1992）や，液位のずれをキャンセルするシリンジポンプの制御方法（平野，森，2015）などが提案されてい る. 本研究は, ゴム栓を貫通する CTSノズルを対象とし, 以下 CTSノズルの課題について検討を行った.

CTS ノズルにおける課題は，挿入荷重の低減，ゴム栓挿抜時のゴムの詰まりや切り屑の発生の抑制，繰り返し 使用可能な耐久性（数百回／日，計 5 万回以上の使用）である. 挿入荷重の低減やゴムの詰まりの問題は, 注射 針においても検討されており, 針先の先鋭化（Yancheng et al., 2013）により挿入荷重を低減し痛みを軽減する研 究（青柳，泉，2008）や，ゴム栓挿入時にゴム栓の一部がくり抜かれて詰まるコアリング現象の検討（朝倉他, 2003）が行われている. また，注射針の穿刺時の反り量についても調査されており（新村他，2012）, 穿刺時に反 ることで目標の挿入角度から変化することが問題となる．ゴム栓挿入時においては，針が斜めに刺さるとコアリ ングが発生しやすくなる報告があり，CTS ノズルにおいても，ゴム栓挿入時に反りが発生しないようにするため 高い座屈荷重の構造が求められる. しかしながら, CTS 分注機構は, 検査スループットを確保するため, 高速で 
CTS ノズルをゴム栓に貫通させる必要があり，その速度は $100 〜 300 \mathrm{~mm} / \mathrm{s}$ 程度（本開発の目標は扱入速度を $150 \mathrm{~mm} / \mathrm{s}$ とした）である. CTS ノズルは注射針と比べ高速かつ繰り返し使用寸るため, コアリングや切り屑の発 生, 挿入荷重がより大きな問題となると考えた. また, 繰り返し切削するツールにおける事例には, 刃物の劣化

（竹腰, 後藤，2004）やドリルの切り屑（吉村他，2016）などあるが，ゴム栓を貫通するノズルにおける挿入荷 重や切り屑低減に関寸る研究事例はない, そこで, 本研究では, CTS ノズル形状と挿入荷重およびゴムの切り屑 との関係を明らかとし，挿入荷重 $50 \mathrm{~N}$ 以下でコアリングせずゴムの切り屑の発生を低減できる CTS ノズルの開 発を行った.

\section{CTS ノズル形状}

\section{$2 \cdot 1$ CTS ノズル基本形状}

CTS ノズルには複数の形状が存在するが, 大きくは液体の吸込・吐出の孔がノズルの先端にあるものと, 側面 にあるものに分けられる (小川, 佐藤, 2010). 図 3，4にそれぞれのノズル形状の例を示寸. 図 3 は先端に吸引・ 吐出用の孔がある CTS ノズルの例で, 斜めに切断された鋭利な先端部でゴム栓を貫通し, 先端の孔からサンプル の吸引と吐出を行う. 先端に孔がある形状では, サンプル吐出のときに液がノズルに残りにくく(液切れが良い), 微量のサンプルを扱う場合に使用される. 特に, 液切れを良くするためには, 液体の表面張力の影響を低減でき る先端径の細い形状が有効である. そのため, CTS ノズルの場合は, 座屈対策のため根元径は太く, 先端径は細 くし, 中間に径を変化させるテーパ部がある.このような形状の CTS ノズルは, ゴム栓挿入方向に孔があるため, ゴム詰まりが問題となりやすい.

図 4 は, 側面に吸引・吐出用の孔がある CTS ノズルの例で, 先端は三角錐状で孔がゴム栓挿入方向にないため, 挿抜時にゴム詰まりは発生しにくい. しかし, サンプル吐出のとき側面から液が出るため, ノズルに液が残りや すく, 生化学自動分析装置で扱うようなマイクロリットルオーダの微量の液を高精度に吐出することが難しい. 孔が側面にあるタイプの先端形状には，この他にも先端が斜め切断されたものや，円錐状のものが存在する.

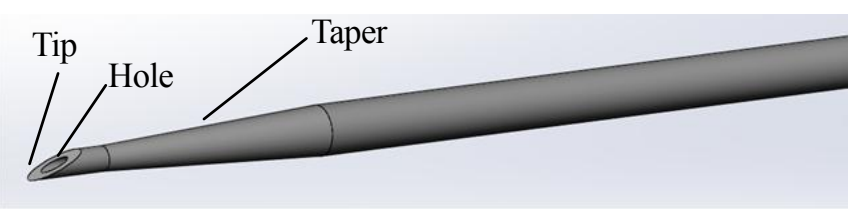

(a) CTS nozzle.

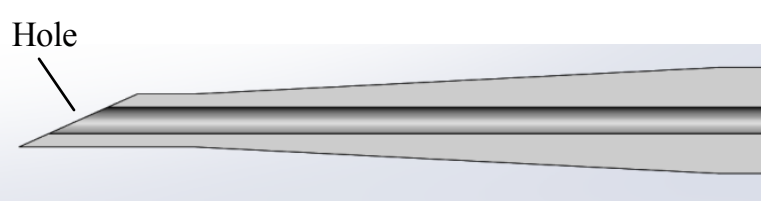

(b) Cross section of CTS nozzle.

Fig. 3 CTS nozzle model (hole at tip). Since there is a hole in the tip of the nozzle, water can be dispensed easily, but it can get clogged with rubber chips.

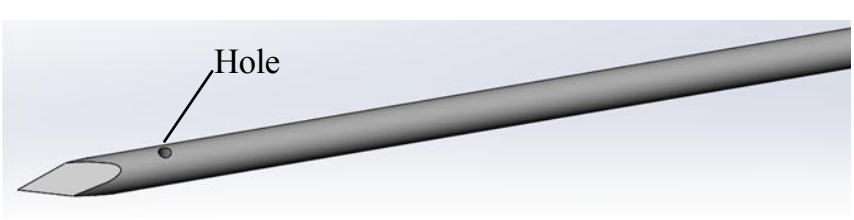

(a) CTS nozzle.

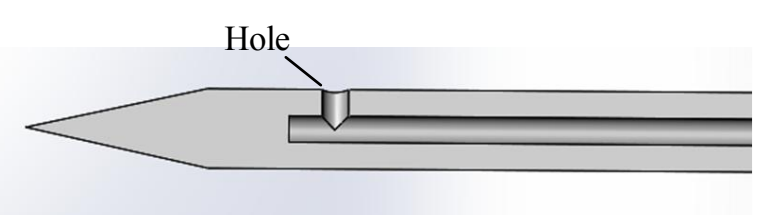

(b) Cross section of CTS nozzle.

Fig. 4 CTS nozzle model (hole at side). The nozzle is less likely to get clogged, but water cannot be dispensed as easily.

以上の特徵から, 本研究では微量の液を扱える先端に孔のあるタイプのノズルを基本形状とし, さらにノズル 先端部には 2 面の切削面を設けることにした. 図 5 に先端部を 2 面切削した CTS ノズルと 1 面のみ切削した従来 のCTSノズルのモデルを示す. CTS ノズルは, 数万回以上ゴム栓を繰り返し貫通するため, ゴムとの摩擦で先端 部が摩耗し，久けやすくなる，そのため，先端部には摩耗した場合も欠けにくい形状が適している．図 5 に示寸 CTS ノズルは，図 5（a）の切削面 $\alpha$ と図 5 （b）の切削面が同じ角度の例であるが，1面を切削した CTS ノズル の方が先端部は薄く欠けやすい形状となる. また, 図 5 (b) の点線は, 2 面切削した CTS ノズルの先端と同じ先 端角度にした場合の形状を示しており，先端の厚さは角度が増えた分だけ厚くなるが，ゴム栓との接触角は 2 面 
切削した CTSノズルよりも鈍角となりゴム栓への挿入負荷は増える. そのため, ゴム栓との接触角が鋭角で先端 の厚さが確保できる2 面切削形状が耐久性確保に適していると考えた.

図 6 にCTSノズルをゴムに押し付けた時のゴムのひずみ分布の計算結果（断面と接触面）を示す. ゴムのひず みは，解析ソフト ANSYS ${ }^{\circledR}$ を使い，あらかじめゴムとノズル先端が接するモデルで接触面に摩擦を定義し，CTS ノズルに強制変位を与えて計算した，計算では，表 1 に示寸物性值を使用した。

解析結果から，先端部を 2 面切削した CTS ノズルは，ゴムのひずみが上下方向に均等に分散しているが， 1 面 切削のものは片側にひずみが偏っていることが分かる．この結果から，ゴムのひずみ分散する先端部を 2 面とし た CTS ノズルの方が，ゴム栓挿入直後にノズルが斜めに挿入することを抑制でき，さらに切削面に偏ったゴム圧 がかからないことで摩耗が発生しにくいと考えた．本解析では，各モデルでノズルの挿入距離の条件を合わせた ため, 2 面切削のものに比べて 1 面切削した CTS ノズルはゴムとの接触面積が小さくなり, ひずみが小さくなっ た。しかし, 先端の耐久性確保のために先端の厚さを増やすことでひずみは増加し, ゴム圧の偏りの影響も増加 すると考えられる. 以下, 先端に吸引・吐出用の孔があり, 先端に 2 面の切削面を持つCTS ノズルにおいて, 挿 入荷重と切り屑に影響する設計パラメータの切り分けを行った.

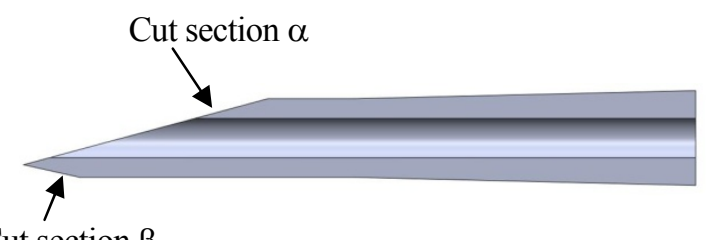

(a) 2-cut section of nozzle tip.

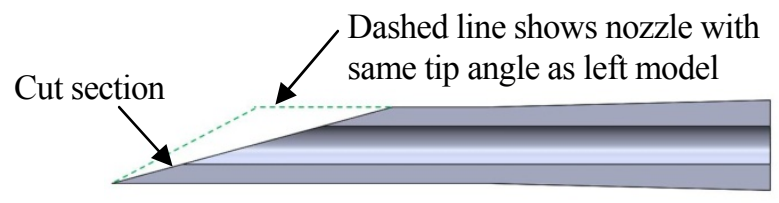

(b) 1-cut section of nozzle tip.

Fig. 5 Tip shapes of CTS nozzle. By making two cuts in the nozzle $(\alpha, \beta)$, the tip does not get too thin. If the nozzle is cut only once with the same angle as (a), the tip cut angle becomes obtuse.

Table 1 Material parameters of analysis.

\begin{tabular}{l|c|c|}
\hline \multicolumn{1}{c|}{ Material } & Young's modulus [MPa] & Poisson's ratio \\
\hline Stainless steel (CTS nozzle) & 197 & 0.30 \\
\hline Rubber & 15 & 0.45 \\
\hline
\end{tabular}
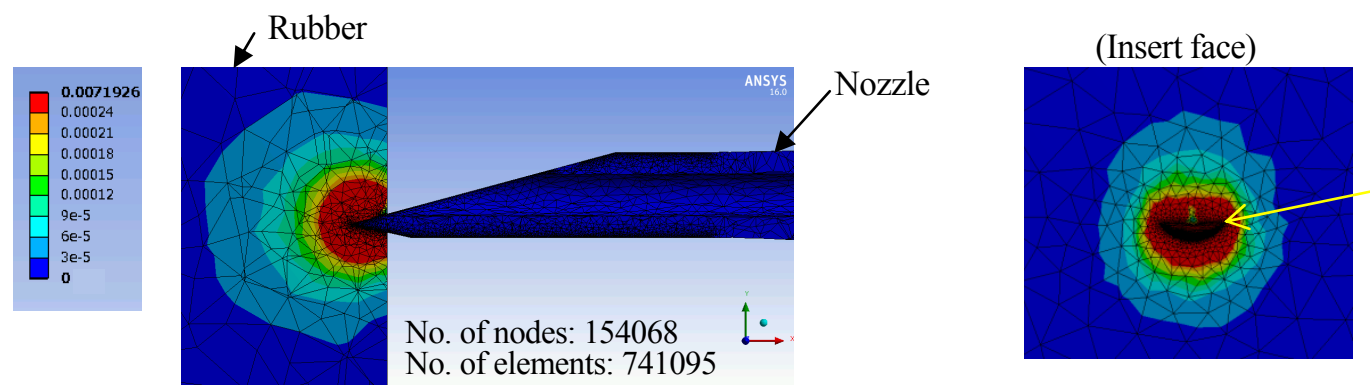

Part of

contact to

nozzle

(a) 2-cut section of nozzle tip.
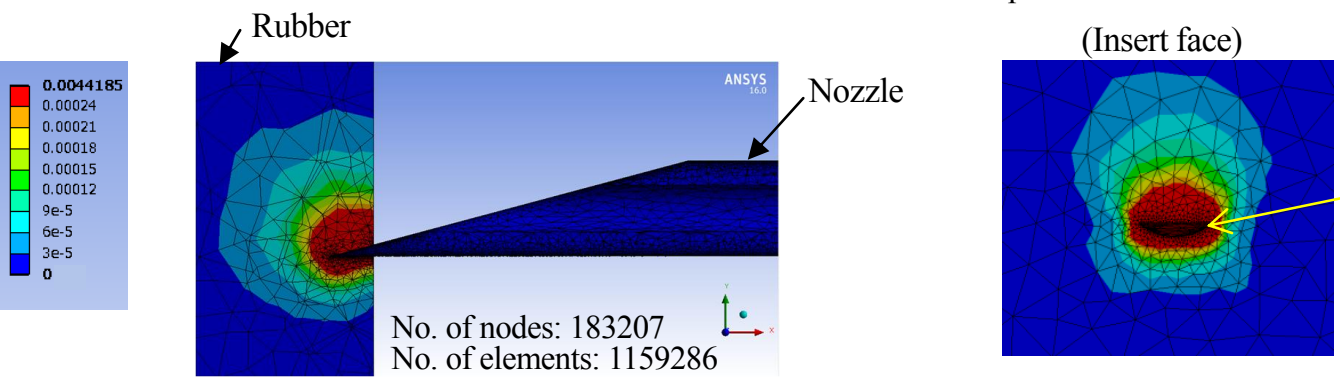

Part of

contact to nozzle

(b) 1-cut section of nozzle tip.

Fig. 6 Analysis of reaction force from rubber by pressing nozzle. The rubber strain is evenly distributed between the upper and lower part in (a) but tends to be biased toward the upper part in (b). 


\section{$2 \cdot 2$ CTS ノズルの設計}

図 7 にCTS ノズルの設計パラメータを示す，ノズル全長と内径は，サンプルの吸引量によって決まり，本研究 では生化学自動分析装置の仕様值からサンプル吸引量を $15 \mu \mathrm{L}$ とした。 また，採血管の長さおよび挿入した CTS ノズルを引き抜く時の採血管浮き上がり防止用の押さえ部などの厚さからノズル長さは $120 \mathrm{~mm}$ 必要で，内径は 中空部の体積を $15 \mu \mathrm{L}$ 以上とするために必要な $0.4 \mathrm{~mm}$ とした. 他の CTS ノズルの設計パラメータは, 表面 コーティングの有無 $(\mathrm{A})$, 根元外径 $(\mathrm{B})$, 先端外径 $(\mathrm{C})$, 刃角 $\alpha(\mathrm{D})$, 先端長 $(\mathrm{E})$, テーパ長 $(\mathrm{F})$, 刃角 $\beta(\mathrm{G})$, 先端の尖り形状（H）である．切削面 $\alpha$ は平面であるが，切削面 $\beta$ は図 7 （b）に示寸通りノズルの円周方向に切 削した 曲面である (刃角 $\gamma$ は刃角 $\alpha$ と刃角 $\beta$ を合わせた角度である).これらのパラメータは，挿入荷重やゴム 栓の切り屑の発生を低減するように設計する必要がある. 本研究では, まず挿入荷重に影響する設計パラメータ の抽出を行い，挿入荷重を低減するための形状の検討を行い，次に挿入荷重に影響しないパラメータでゴム栓の 切り屑の発生を低減する形状を検討した.

挿入荷重に影響するパラメータを抽出するため, パラメータ $\mathrm{A} \sim \mathrm{H}$ の挿入荷重に対する感度を実験計画法（柏 村他，1996）で検討した. 表 2 に制御因子を示す.コーティング（A）には，表面を平滑にでき金属の摩擦係数 を下げることに利用される DLC（Diamond-like Carbon）を膜厚約 $2 \mu \mathrm{m}$ で塗布した.

また, 先端の尖り形状（H）は，図８に示寸通り，先端の切削角度 $\alpha$ (D) によってできた先端の楕円状の面の 角を切り落とすことで先鋭となるパラメータで，角度が大きいほど先鋭となる．今回は， $0^{\circ}$ （加工なし） $30^{\circ}$ $145^{\circ}$ とした. 他のパラメータは表 2 に示寸通りとした. 以上のように決定した 8 種類の制御因子と L18 直交表を 基に，18 種類の形状の CTS ノズルを試作した.

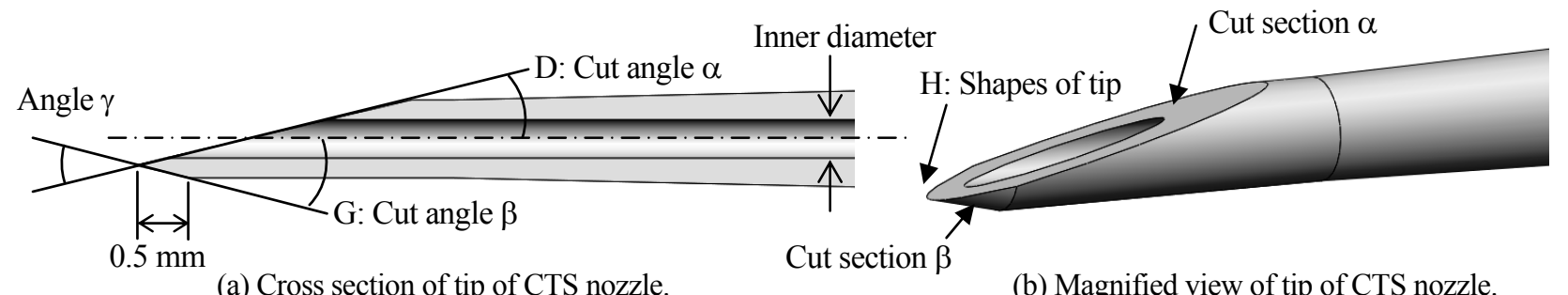

(a) Cross section of tip of CTS nozzle.

(b) Magnified view of tip of CTS nozzle.

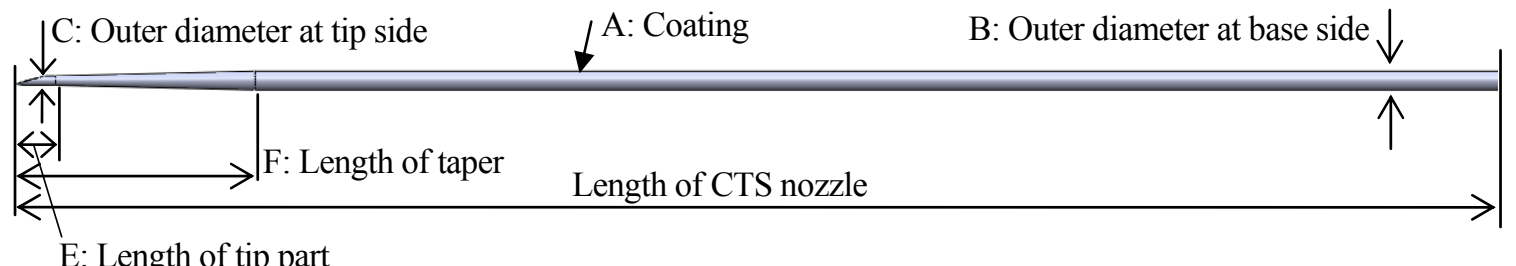

(c) Overall view of CTS nozzle.

Fig. 7 Design parameters of CTS nozzle.

Table 2 Control factors of Taguchi method.

\begin{tabular}{l|c|c|c}
\hline \multicolumn{1}{c|}{ Control factor } & Level 1 & Level 2 & Level 3 \\
\hline $\mathrm{A} \quad$ Coating & with & without & - \\
\hline $\mathrm{B} \quad$ Outer diameter of base side $[\mathrm{mm}]$ & 1.5 & 1.6 & 1.7 \\
\hline $\mathrm{C} \quad$ Outer diameter of tip side $[\mathrm{mm}]$ & 0.6 & 0.7 & 0.8 \\
\hline $\mathrm{D} \quad$ Cut angle $\left.\alpha{ }^{\circ}\right]$ & 12 & 15 & 18 \\
\hline $\mathrm{E} \quad$ Length of tip part $[\mathrm{mm}]$ & 3 & 4 & 5 \\
\hline $\mathrm{F} \quad$ Length of taper $[\mathrm{mm}]$ & 9 & 12 & 15 \\
\hline $\mathrm{G} \quad$ Cut angle $\beta\left[^{\circ}\right]$ & 8 & 10 & 12 \\
\hline $\mathrm{H} \quad$ Shapes of tip $\left[{ }^{\circ}\right]$ & $0 \quad$ (without) & 30 & 45 \\
\hline
\end{tabular}




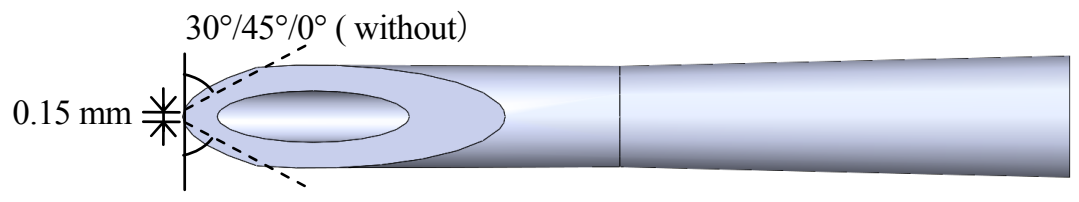

Fig. 8 Design parameter $\mathrm{H}$ (shapes of tip).

\section{$2 \cdot 3$ 挿入荷重に影響するパラメータの検討}

挿入荷重の測定では，CTSノズルを高速かつ一定速度で採血管に垂直に挿入するため，CTS ノズルを自動で移 動でき同時に荷重の測定が可能な装置を構築した．図 9 にノズルの挿入荷重測定装置を示す．リニアステージの テーブル上に荷重センサを固定し，その先端部には治具を介して試作した CTS ノズルを固定した．さらに，ス テージの進行方向に採血管を治具で固定し，一定速度になる区間でゴム栓をノズルが通過できるように位置を調 整した。この他に, 荷重データを記録するため, 荷重センサはチャージアンプを介して, ロガー（サンプリング $10 \mathrm{kHz}$ ) に接続した. 測定に使用した採血管は図 9 に示した 2 種類 $\left(B D\right.$ Vacutainer $^{\circledR}$, カタログ番号 367861,367840 ) とした. CTS ノズルの挿入速度は，挿入速度と最大荷重の関係（図 10）から，線形に増加する傾向を示した $300 \sim 500 \mathrm{~mm} / \mathrm{s}$ の範囲とし，300，400，500 mm/s の 3 種類で評価した. 目標挿入速度 $150 \mathrm{~mm} / \mathrm{s}$ に比べ高速での評 価となったが，挿入荷重に対する感度を調べる上では問題ないと考えた. なお，採血管のゴム栓部は厚さ約 $6 \mathrm{~mm}$ で，材質はブチルゴム（ゴム硬度 40〜50 度）と推定される.
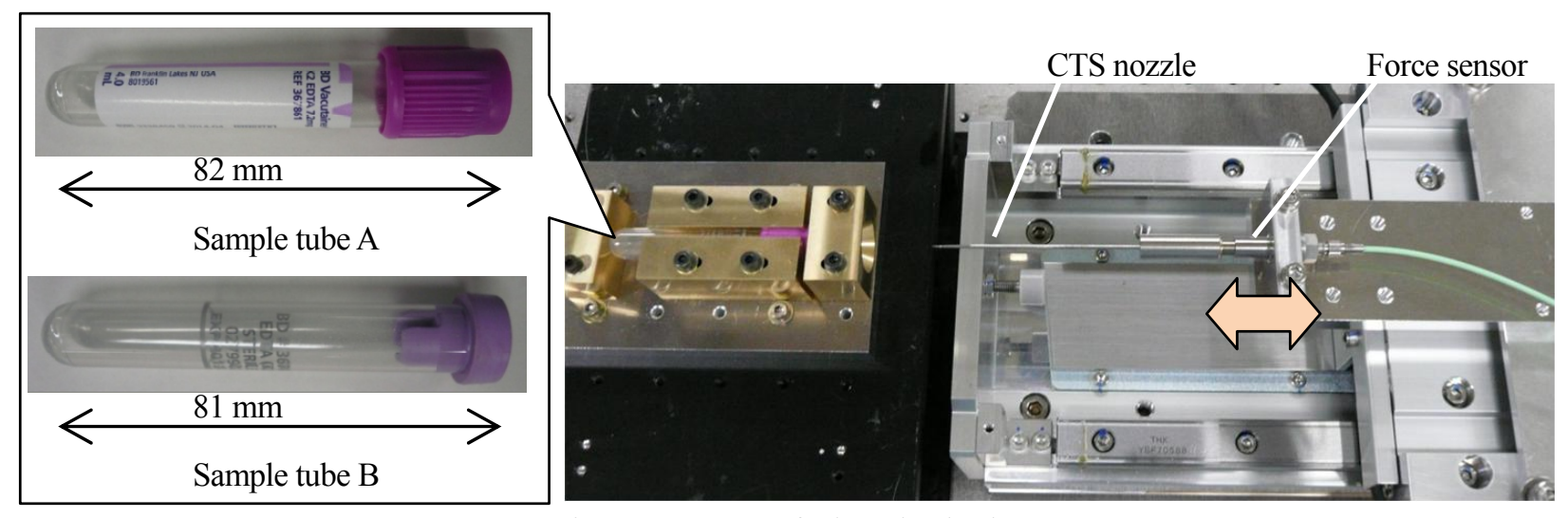

Fig. 9 Instrument for insertion load measurement.

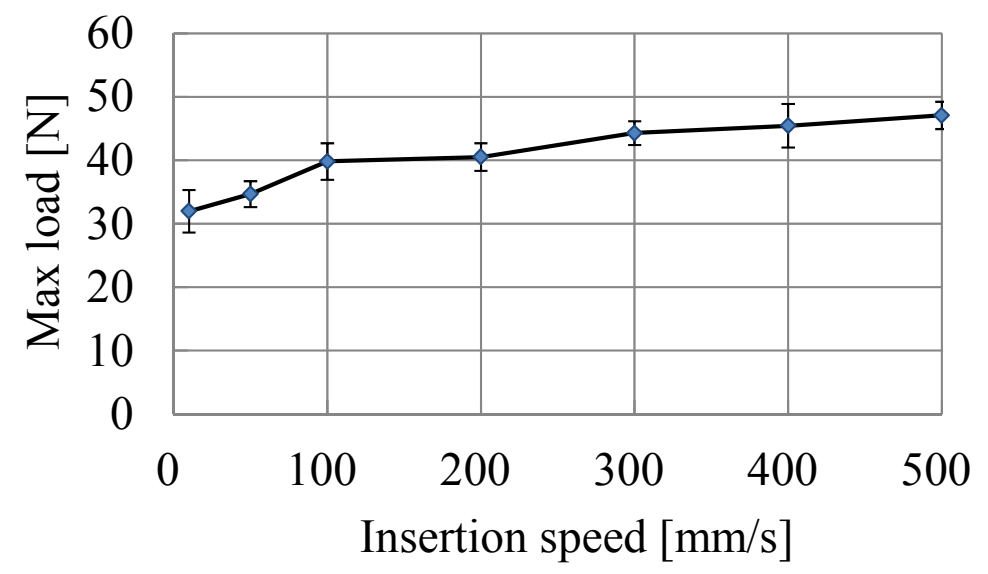

Fig. 10 Relationship between insertion speed and maximum load. 
図 11 に試作したCTSノズル（DLC なし，先端部長さ $5 \mathrm{~mm}$ ，テーパ長 $12 \mathrm{~mm}$ ）をゴム栓の厚さ約 $6 \mathrm{~mm}$ の採 血管に挿入したときの荷重波形の例を示す. CTS ノズルの位置との関係を検討するため，グラフの横軸はゴム栓 の挿入距離に変換した. 挿入時の最大荷重は $41 \sim 43 \mathrm{~N}$ (速度 $150 \mathrm{~mm} / \mathrm{s}$ は約 $40 \mathrm{~N}$ ) で, 速度に比例して増加した. また，荷重波形には最大荷重となる前に荷重の増加傾向が変化する特徵点が 2 点あった.

図 11 から, 特徵点 $1(2 \mathrm{~mm})$, 特徵点 $2(8 \mathrm{~mm})$, 最大荷重点 $(17 \mathrm{~mm})$ は挿入速度に関係なく同じ位置で, 特 徵点 1 は CTS ノズルの先端から先端の孔のエッジまでの距離と一致し, 特徴点 2 はこの長さにゴム栓の厚さ （6 mm）を合わせた長さ $8 \mathrm{~mm}$ と一致する. さらに, 最大荷重点はテーパ長（12 mm）とゴム栓の厚さを合わせ た長さと概ね一致する．このことから，特徴点 2 までの間で，CTS ノズル先端の刃がゴムを切断すると同時に テーパ部がゴムを広げ始めるため, 特徵点 1 までの傾きと特徵点 1 から特徴点 2 までの傾きは異なり, 特徵点 2 から最大荷重の間は，一定傾斜のテーパ部がゴムを広げるため荷重増加が一定の傾きとなっていると考える．ま た，注射針では，外径の変化がない（テーパ部がない）ため, 特徵点 1 付近が最大荷重となり針先の形状が挿入 荷重に影響するが，CTSノズルはテーパ部の影響が大きく先端形状の影響が小さい結果となった.

試作した 18 種類のノズル，2 種類の採血管， 3 種類の挿入速度で測定した最大荷重から，各設計パラメータの 感度を計算した. 図 12 に感度解析の結果を示寸. 図中の感度値は低いほど扦入荷重が低いことを示している. 結 果から, 挿入時の最大荷重に影響寸る主な因子は, A コーティング, B 根元外径, $\mathrm{C}$ 先端外径, F テーパ長で あった．逆に，CTS ノズルの先端形状（刃角など）は挿入荷重に対して影響が低いことが確認されたＡ ティングに関しては, DLC コーティングを行わない方が低荷重であった. これは, CTSノズルの表面をコーティ ングしたことで表面が滑らかになり，ゴムとの密着性が上がったことで摩擦力が逆に増えてしまったものと考え る. また， B 根元外径は細い方が低荷重となるが， C 先端外径は逆に太い方が低荷重で，F テーパ長が延びる方 向が低荷重となる傾向から, 挿入荷重低減には CTS ノズルのテーパ角度を小さくすることが有効であると言える.

以上のように, 感度の高いパラメータ A， B，C，Fに比ベ他のパラメータの感度は低く, ゴム栓の切り屑の発 生低減には，扦入荷重への影響が少ないパラメータ $\mathrm{D}, \mathrm{G}$ （刃角 $\alpha, \beta$ ）を用いることにした，そこで，先端形状 は設計を単純化するため $\mathrm{H}$ 先端の尖り形状は加工なしとし, さらに刃角 $\alpha$ を浅い角度とする(切削面 $\alpha$ が広がる) ため, $\mathrm{E}$ 先端長は $3.5 \mathrm{~mm}$ と余裕を持たせた。挿入荷重低減に対しては, A コーティング (なし), C 先端外径 $(0.8 \mathrm{~mm})$ とし, F テーパ長は加工方法を再検討しさらに $20 \mathrm{~mm}$ まで延長した. 挿入荷重と座屈荷重の両方に影 響する B 根元外径は座屈荷重を計算して決定した.

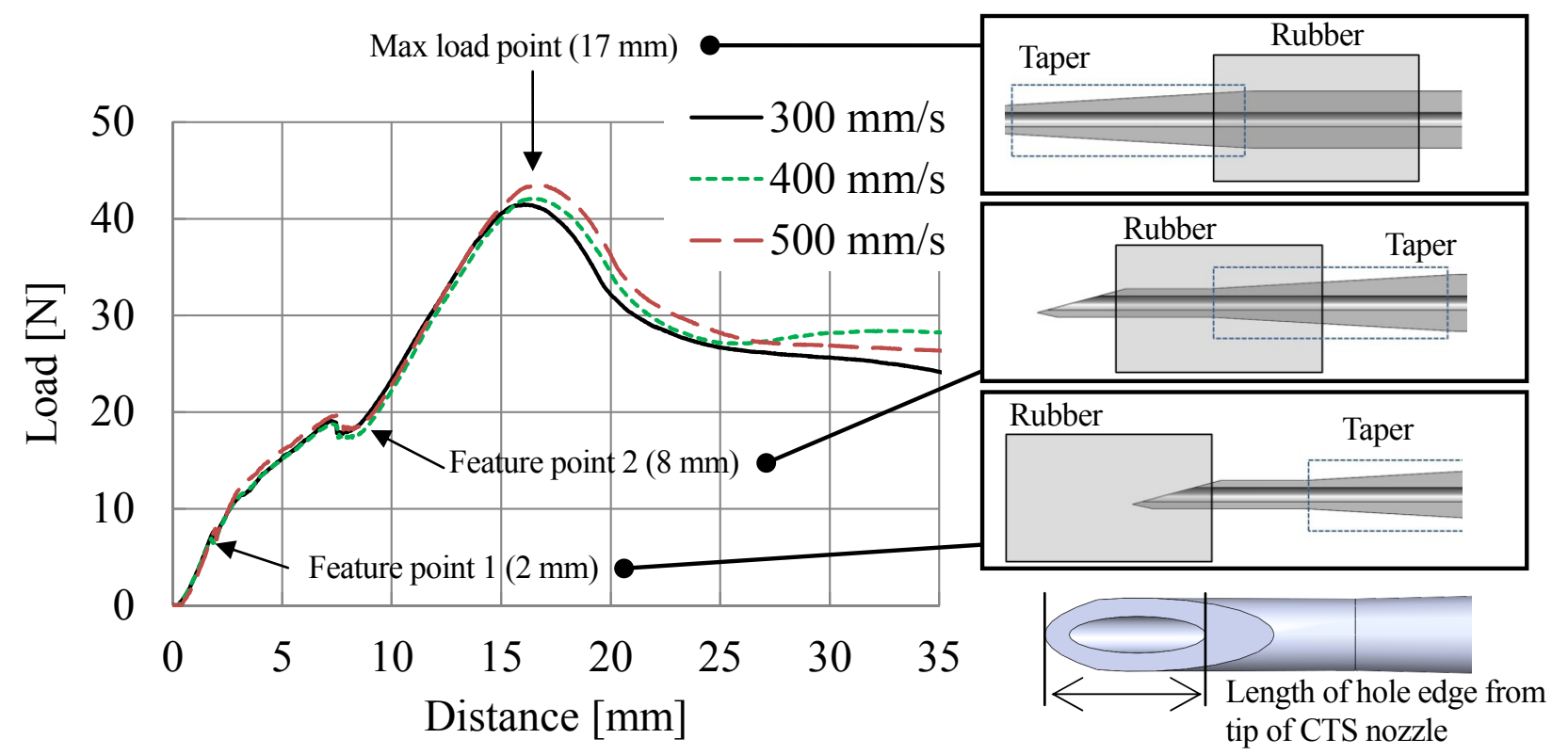

Fig. 11 Load data of CTS nozzle inserted through rubber cap. Using this chart, it is possible to extract two feature points. Feature point 1 refers to the moment when the edge of the nozzle hole comes into contact with the cap. Feature point 2 refers to the moment when this same hole edge passes through the cap. Furthermore, the highest load refers to the moment when the thickest diameter of the taper passes through the cap. 


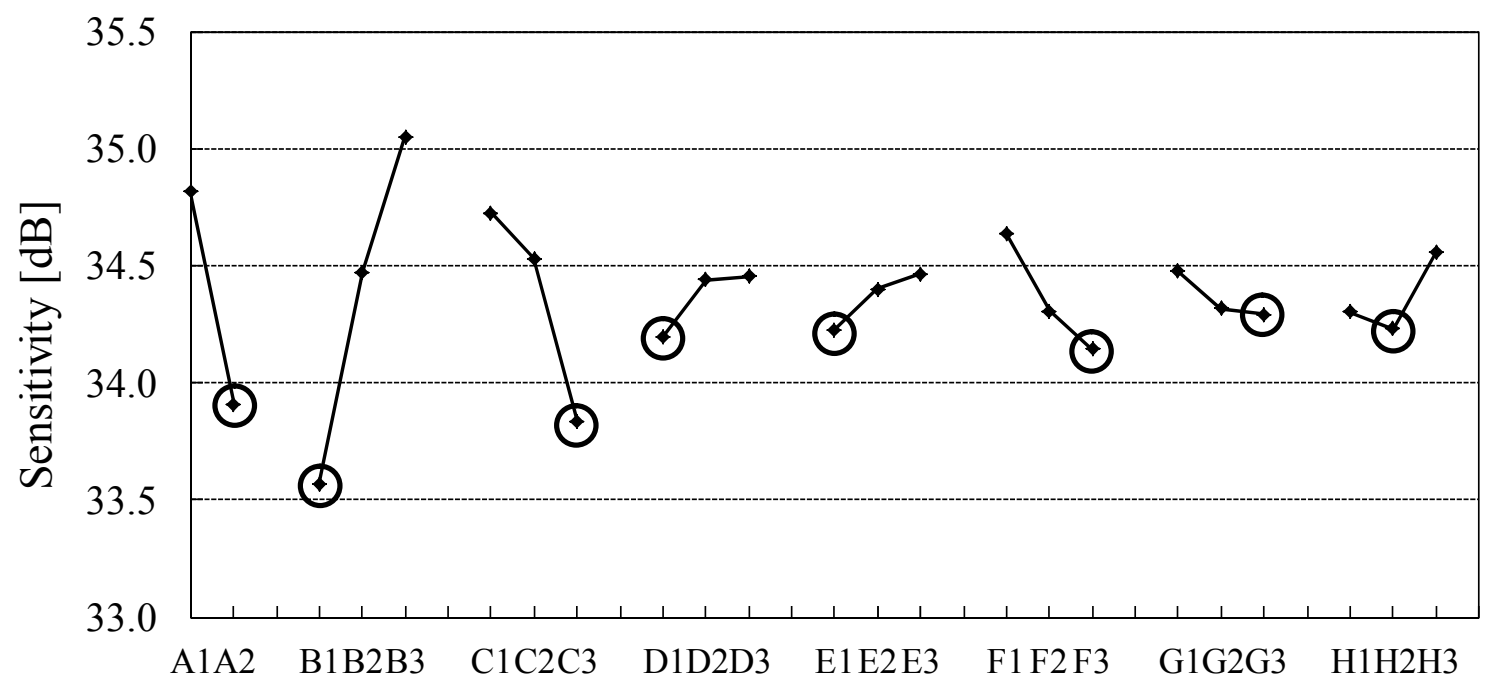

Fig. 12 Sensitivity of CTS nozzle inserted through rubber cap. Load is more influenced by parameters A, B, C, and F.

座屈荷重は, 内外径が一様な中空円柱の場合, 内外径による断面 2 次モーメントと円柱の長さから求められる. 長さと内径は仕様により決まっているため, CTS ノズルでは, 根元外径が座屈荷重に対して影響度が高い設計パ ラメータである. 図 13 に根元外径と座屈荷重および挿入荷重値（試作した 18 種の CTS ノズル $\phi 1.5 \sim \phi 1.7 \mathrm{~mm}$ のデータから推定）を示す. CTS ノズルの座屈荷重は, 解析ソフトの座屈解析で計算した. この結果から, 安全 率が 2.0 以上となる条件は外径 $\phi 1.6 \mathrm{~mm}$ 以上であり, 挿入荷重が $50 \mathrm{~N}$ 以下となる条件は外形 $\phi 1.7 \mathrm{~mm}$ 以下で あった. B 根元外径は挿入荷重の低い $\phi 1.6 \mathrm{~mm}$ に決定した.

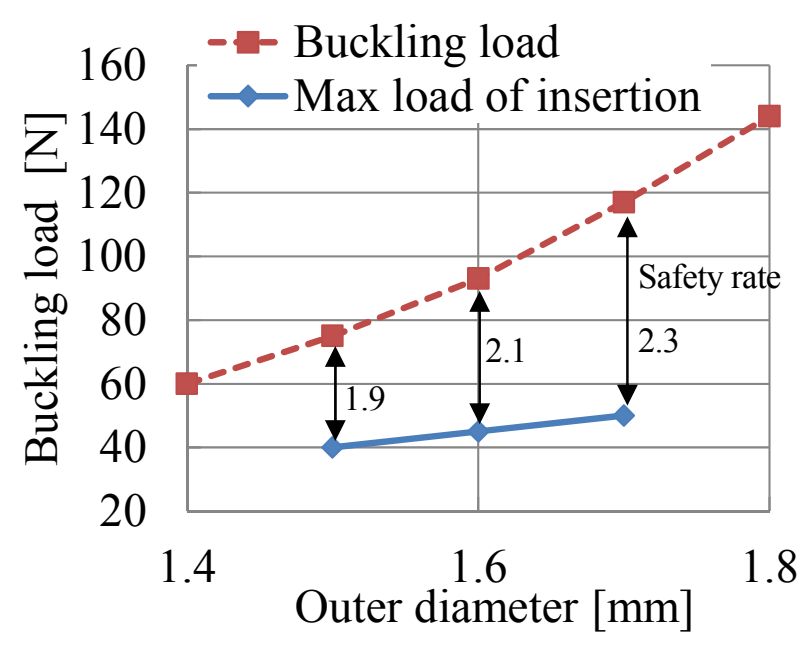

Fig. 13 Buckling load of CTS nozzle. The condition for securing a safety factor of more than 2 against the bucking load was a nozzle outer diameter of $1.6 \mathrm{~mm}$ or more, and the condition under which the insertion load was under $50 \mathrm{~N}$ was a nozzle outer diameter of $1.7 \mathrm{~mm}$ or less.

\section{$2 \cdot 4$ ゴム詰まりと切り屑の検討}

ゴムの切り屑の評価を行うため，まずゴム栓挿抜によってコアリングが発生していないかを確認した．図 14 にCTSノズルを厚さ $6 \mathrm{~mm}$ のゴム栓に速度 $150 \mathrm{~mm} / \mathrm{s}$ で挿入したあとの CTS ノズル先端と内部にあったゴム屑の 写真を示寸. 図 14 （a）のようにCTS ノズルの孔の内側にゴムの詰まり（コアリング）が発生し，そのゴムを取 り出したところ図 14 (b) のような形状であった. 
図 15 にCTSノズルにおけるゴム詰まりの推定メカニズムを示寸. 先端に孔があるタイプの CTS ノズルには, 鋭角（エッジ）となる部分が 2 か所できる（先端側をエッジ 1 ，根元側をエッジ 2 と呼ぶ)．ゴム栓に CTS ノズ ルを挿入するとき，まず先端側エッジ 1 がゴム栓を切り開き，CTS ノズルの側面がゴムを押し分けて進んでいく が，ノズル先端の孔にはゴムの一部が入りこんでくる（状態 a)，その後，孔に入ったゴムは，根元側エッジ 2 で 次第に切り取られ（状態 b), 切り取られた細長いゴム片はCTS ノズルの奥に入り込んでいく（状態 $\mathrm{c}$ ). CTS） ズルがゴム栓から抜け出ると，ノズル内に入ったゴムはエッジ 2 で切り取られ残留し詰まりとなる. 先端に 2 面 の切削面を設けてゴム圧が分散したとしても，切削によって鋭角となったエッジ 2 にゴムが接触することでゴム は削られる，そこで，エッジ 2 でゴムが切り取られないように，切断面 $\alpha$ の角部を研磨して丸めることでゴムの 詰まり（コアリング）をなくした.

これまでの検討から, CTS ノズルの先端形状は挿入荷重への影響度が低いことが確認されているので, 刃角 $\alpha$, $\beta$ （パラメータ $\mathrm{D}, \mathrm{G}$ ) による切り屑低減を検討した. 表 3 に刃角の組合せと, 切り屑の発生率を示す. それぞれ 7 回の挿抜試験（挿入速度 $150 \mathrm{~mm} / \mathrm{s}$ で各測定には未挿入の採血管を使用）を行い，ノズルに付着した切り屑

（図 16 のような $0.2 \mathrm{~mm}$ 以上の目視可能なサイズ） が 1 個以上発生した回数をカウントした. 実験から, 刃角 $\alpha$ が 15 度で, 刃角 $\gamma$ が 27〜28.5 度の形状では, 切り屑の発生が確認できなかった. この要因を検討するため, 捙 抜に使用した採血管のゴム栓を観察した。
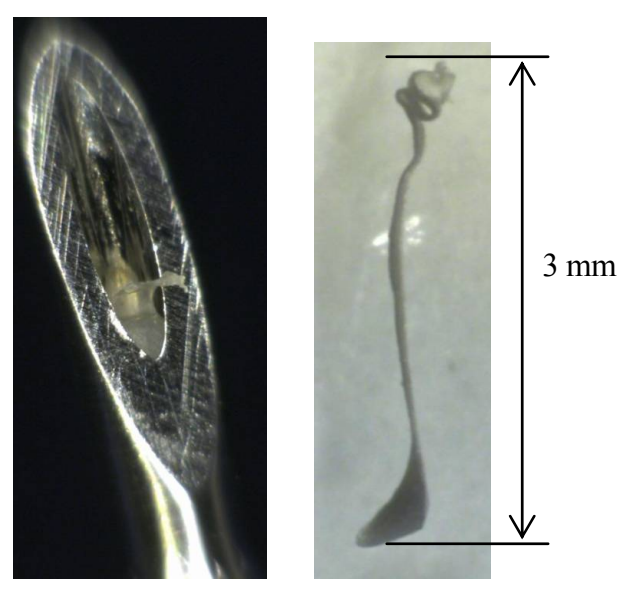

(a) CTS nozzle.

(b) Rubber waste.

Fig. 14 Rubber clogging. A long thin rubber chip was left inside the nozzle after insertion. (a) Edge 1

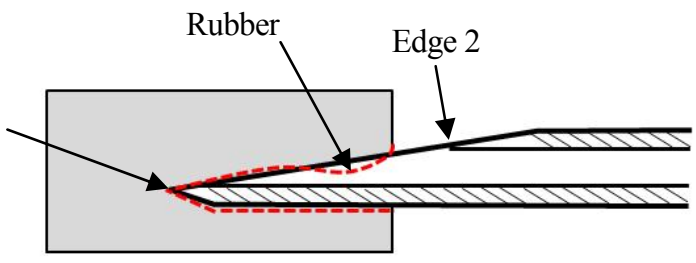

(b)

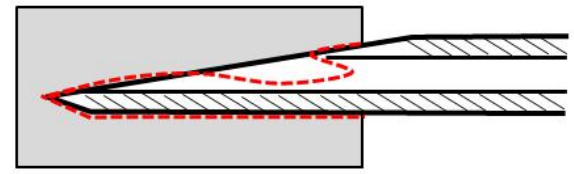

(c)

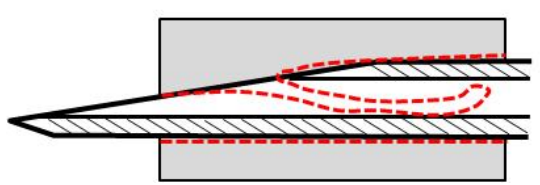

Fig. 15 Mechanism of rubber clogging. It is assumed that when the nozzle is inserted, the rubber is inserted into the hole and edge 2 cuts the rubber. As the nozzle moves inside the cap, the rubber is pushed inside the nozzle, forming the long chip shape.

Table 3 Number of occurrences of rubber waste.

\begin{tabular}{c|c|c|c|c|c|c|c|c|c}
\hline \hline Nozzle no. & 1 & 2 & 3 & 4 & 5 & 6 & 7 & 8 & 9 \\
\hline Cut angle $\alpha\left[^{\circ}\right]$ & 9 & 9 & 12 & 12 & 15 & 15 & 15 & 18 & 18 \\
\hline Cut angle $\beta\left[^{\circ}\right]$ & 12 & 13.5 & 12 & 13.5 & 12 & 13.5 & 15 & 13.5 & 15 \\
\hline $\begin{array}{c}\text { Cut angle } \gamma\left[^{\circ}\right] \\
(\text { angle } \alpha+\text { angle } \beta)\end{array}$ & 21 & 22.5 & 24 & 25.5 & 27 & 28.5 & 30 & 31.5 & 33 \\
\hline Number of occurrences & $2 / 7$ & $3 / 7$ & $2 / 7$ & $2 / 7$ & $0 / 7$ & $0 / 7$ & $3 / 7$ & $2 / 7$ & $4 / 7$ \\
\hline
\end{tabular}




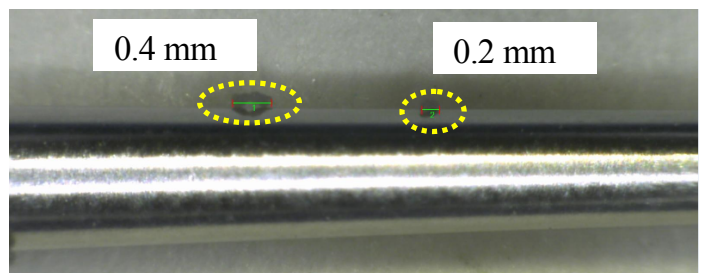

Fig. 16 Example of rubber waste attached to CTS nozzle (taper part ).

図 17 にゴム栓のノズル通過部付近の拡大写真を示す. 図 17 から, エッジ 1 の通過部の切り口は, (a) (b) で は削られた部分も少なく切り屑の発生に影響は少ないと考えられるが，(c) ではゴムの切り口が荒らされており 切り屑となる可能性がある．逆に，エッジ2の通過部は，(a)（b）で削られた部分が発生しており切り屑となる 可能性が高いが，(c) では削られた部分はほとんどなく切り屑発生には影響しないと考えられる. これらの傾向 を基に，切り屑が発生するメカニズムを検討した。

図 18 にCTS ノズルがゴム栓を通過したときのゴムの変形状態を示す. ゴム栓をCTSノズルが通過するときは, 先端エッジ 1 がゴムを切り開き（状態 $\mathrm{A}$ ), 先端の肉厚部がゴムを押し広げ（状態 B), ゴム栓通過途中でエッジ 2 と接触（状態 C）し，その後ノズル側面がゴムを押し広げていく（状態 D). 状態 D では，ノズル外径の変化に よりゴムの変形量が変化する. 状態 A では, 刃角 $\gamma$ が鈍角でゴムの切断性が悪い場合, ゴムがノズルの進行方向 に引き伸ばされる（あるいは押しつぶされる）ため, 図 17 (c) のエッジ 1 通過部のように荒れた状態となる. 逆に, 刃角 $\gamma$ が鋭角であれば, 図 17 （a）（b）のエッジ1通過部のような状態となる. 次に, 状態 Cでは, エッ ジ 2 が鋭角である場合，ノズルの開口部に入ってきたゴムとエッジ 2 の接触によってゴムが削られる. このとき の接触痕が図 17 のエッジ 2 通過領域であり，エッジ 2 が鈍角である図 17 (c) は接触痕が小さくなっている.， ズルの各エッジは，ゴム栓内部でもゴムと接触しながら移動するため，ゴム栓の表面と同様にノズル通過部のゴ ムは剥がれや寸くなるものと考えられる，ノズル通過部で剥がれやすくなったゴムは，ノズルの移動による摩擦 で剥がれ,これがノズル引き抜き時に付着することで図 16 のような切り屑となるものと考える. 今回の検討では, ゴム栓内部の状態は観察できていないため, 今後より詳細の検討が必要であると考える.

以上の推定メカニズムから, 刃角 $\gamma$ が鈍角であるとエッジ 1 のゴムの切断性は低く, 刃角 $\gamma(\alpha+\beta)$ が 30 度以 上でゴムの切断性が不十分となりゴムを荒ら寸. 逆に, 刃角 $\alpha$ が鋭角であるとエッジ 2 の切断性は高く, 刃角 $\alpha$ が 12 度以下でゴムを削りやすくなると考えられる. そのため, 今回の評価では刃角 $\alpha$ と $\beta$ が中間值 $(\alpha: 15$ 度, $\beta: 12,13.5$ 度) の条件で, ゴム屑の発生が確認できなかったものと考える.ただし, エッジ 2 に関しては, 研磨 で丸めることで影響を抑制できるものと考えられる．以上から，先端が 2 面ある CTS ノズルでは，切り屑の発生 頻度の少なくなる刃角の組み合わせに加え研磨処理を行うことで，切り屑の発生を低減可能である.

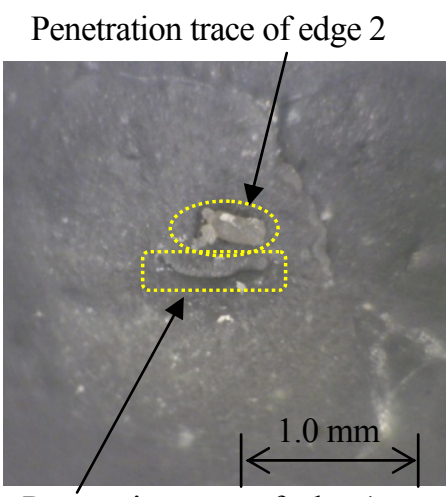

Penetration trace of edge 1

(a) Nozzle no.1.

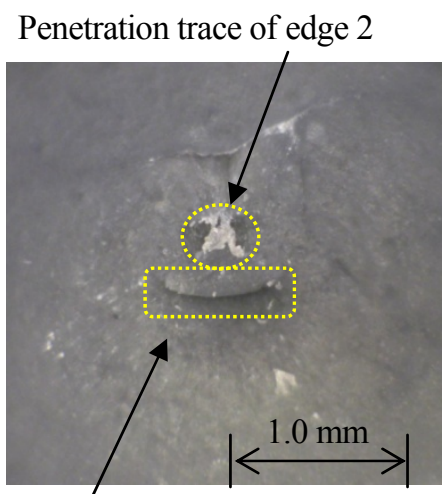

Penetration trace of edge 1

(b) Nozzle no.5.

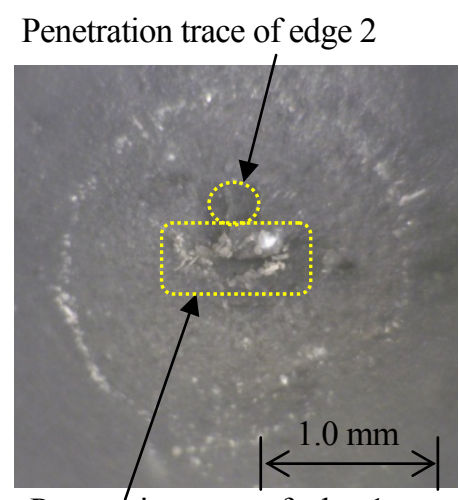

Penetration trace of edge 1

(c) Nozzle no.9.

Fig. 17 Picture of rubber cap after penetration. When the angle of edge 1 is obtuse, the penetration area shown in the lower part of the pictures is scraped by friction. When the angle of edge 2 is obtuse, the penetration area shown in the lower part of the pictures is scraped by friction. 


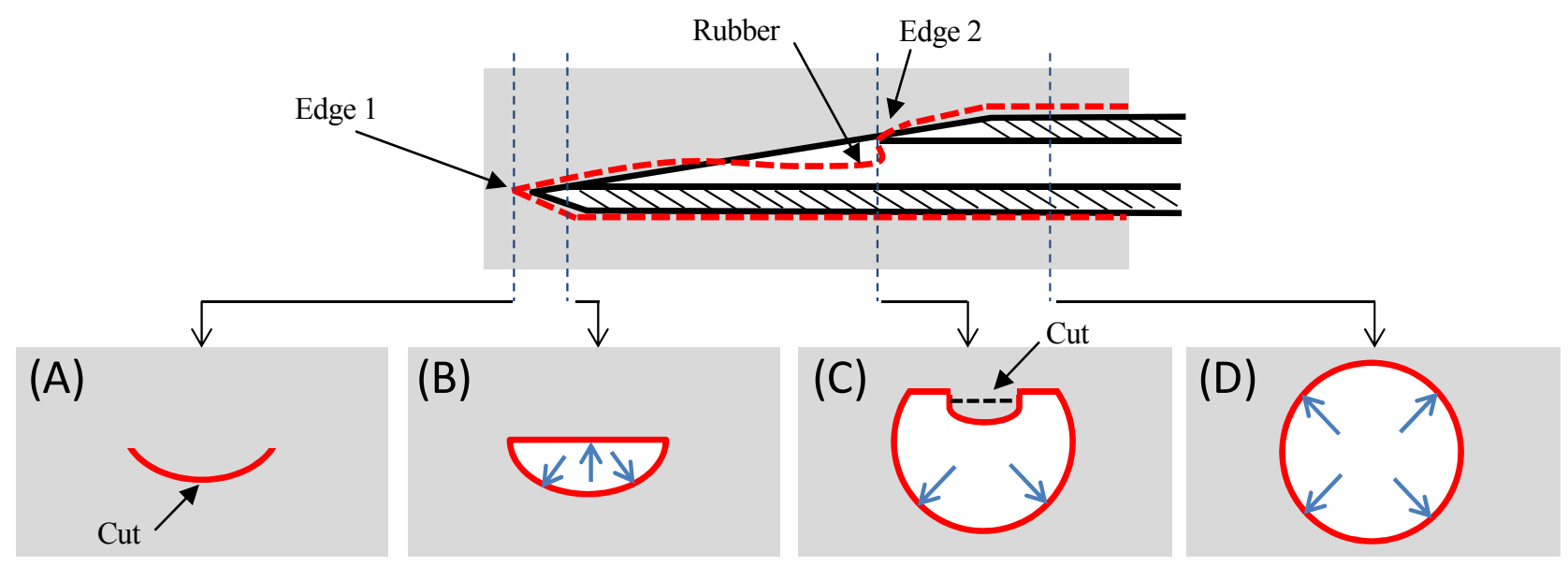

Fig. 18 Transformation of rubber by nozzle insertion. Rubber is cut by edge 1 and edge 2 during status (A) and (C).

\section{CTSノズルの評価}

これまでに決定した CTSノズルのパラメータをまとめると，A 表面コーティングなし，B 根元外径 $\phi 1.6 \mathrm{~mm}$, $\mathrm{C}$ 先端外径 $\phi 0.8 \mathrm{~mm}, \mathrm{D}$ 刃角 $\alpha 15$ 度, $\mathrm{E}$ 先端長 $3.5 \mathrm{~mm}, \mathrm{~F}$ テーパ長 $20 \mathrm{~mm}, \mathrm{G}$ 刃角 $\beta 12.5$ 度, $\mathrm{H}$ 先端の尖り形状 追加工なしであり, これに切削面 $\alpha$ の角部を丸める研磨を加えたものを最終形状とした. 最終形状のCTSノズル で測定した挿入荷重值から，ゴム詰まり対策として追加した研磨が，扦入時の最大荷重に影響することが分かっ た．そこで, 座屈荷重の安全率が 2.0 以下となる範囲で, エッジ 2 がゴムを削らないようにするため研磨時間を 増やした。研磨前の最大扦入荷重は $34 \mathrm{~N}$ で, これに挿入荷重が $40 \mathrm{~N}$ 程度（座屈荷重の安全率が 2.0 以上となる 条件）となるまで研磨を追加した。図 19 に試作した最終形状の CTS ノズルの研磨前後の写真を示す. 研磨前後 の先端開口部の寸法から, 研磨によって角がおよそ $35 \mu \mathrm{m}$ 丸められていた. 刃面 $\alpha$ を研磨したことで, 刃面 $\alpha$ に あった角が落ち丸められているが，先端の刃角 $\gamma$ には影響していない。

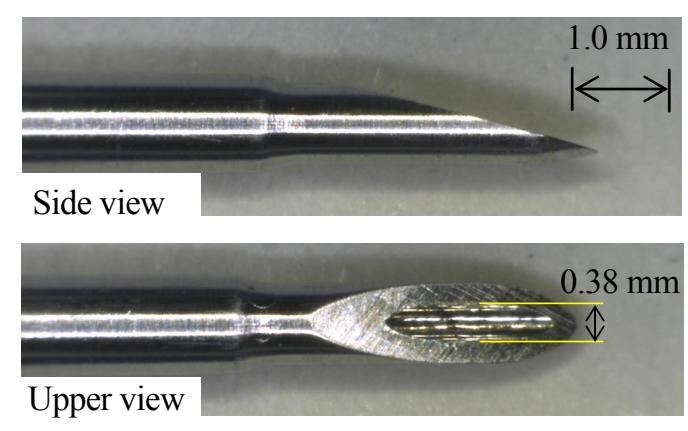

(a) Before polishing.

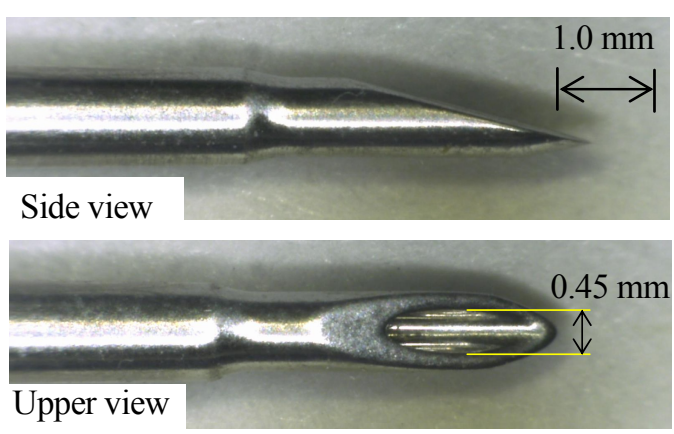

(b) After polishing.

Fig. 19 CTS nozzle before and after polishing.

図 20 に最終形状の CTS ノズル（研磨後）を貫通したあとのゴム栓の写真を示寸. エッジ 1 の通過した切り口 はゴムがつぶれることなく切れており，エッジ 2 が接触した部分もゴムが削られた痕が少ないことが分かる．こ の結果から, 先端の刃角を調整することで, ゴムの切り屑の発生を低減できることが確認された. 最終形状の CTS ノズル (研磨後) は, 10 回のゴム栓挿抜試験を行ったがゴムの切り屑は確認されなかった.

最後に，CTSノズルの耐久性を調べるため，ゴム栓と同じ材質（ブチルゴム）の板（厚さ $6 \mathrm{~mm}$ ）を作り, CTS ノズルが通過していない位置を繰り返し挿抜していくテストを行った. 図 21 にテスト前後の CTS ノズルの㑯面 からの写真を示す． 5 万回以上の挿抜を行ったが，先端部がわずかに摩耗で丸まったのみで刃の欠けや刃角 $\gamma$ の 変化は発生しないことが確認できた. テスト後の CTS ノズルはゴム栓への最大挿入荷重も変化なく挿入できた. 


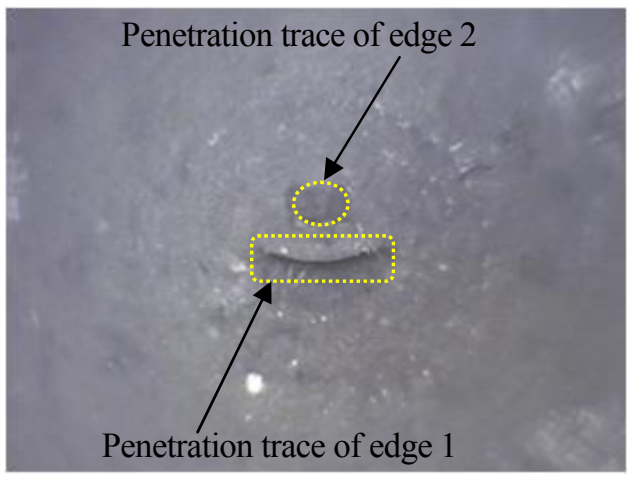

Fig. 20 Picture of rubber cap after penetration (CTS nozzle with final shapes). Almost no signs of scrapes due to passage of edges 1 and 2.
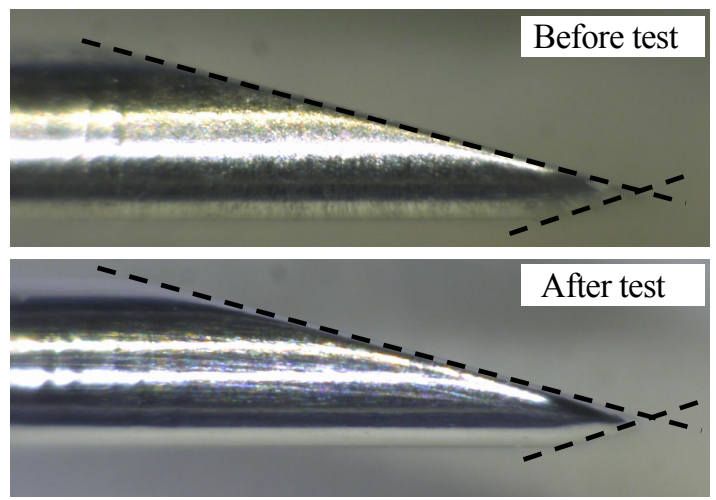

Fig. 21 CTS nozzle before and after durability test (50,000 insertions). After the test, almost no signs of abrasion were found in the nozzle.

\section{4. 結語}

採血管のゴム栓を取り外さずに内部のサンプルを分注する CTS 機能の装置実装を目指し，挿入荷重 $50 \mathrm{~N}$ 以下 でゴム栓を貫通して内部のサンプルを分注できる CTS ノズルの開発を行った. 本研究では, 微量の液が扱える先 端に孔のある形状を基に, ノズル形状と挿入荷重およびゴムの切り屑との関係を検討し, 以下の結論を得た。

（1）実験計画法の L18 直交表を基に CTS ノズルの挿入荷重に対する感度解析を行った．その結果，挿入荷重に 対して感度が高いパラメータはテーパ角であり，これを小さくすることが有効であることを明らかとした． 本開発では, 先端外径 $\phi 0.8 \mathrm{~mm}$, 根元外径 $\phi 1.6 \mathrm{~mm}$, テーパ長 $20 \mathrm{~mm}$ のノズル形状とすることで, 厚さ $6 \mathrm{~mm}$ ゴム硬度 40～50 度のゴム栓に対する挿入荷重を $34 \mathrm{~N}$ （座屈荷重に対する安全率 2.1）とした.

(2) CTS ノズル抻抜によって発生するゴムの切り屑は, 先端を切削した際に形成される 2 か所のエッジとなる 部分の影響が強く, 先端側エッジは鋭角 (28.5 度以下), 根元側エッジは鈍角（15 度以上）となる刃角の組 合せによってゴムの切り屑の発生を低減できた. さらに，コアリングの対策として根元側エッジを丸める研 磨処理が有効であり, 先端側エッジ 27.5 度, 根元側エッジ 15 度としたノズルに研磨処理を加えることで, 目視で確認できるサイズ $(0.2 \mathrm{~mm}$ 以上) の切り屑が発生しないことが確認できた.

（3）ゴム栓に対する接触角の鋭角化とノズル先端部の厚さ（耐久性）確保を両立するために，ノズル先端部の切 削面を 2 面とした CTS ノズルは，ゴム板に 5 万回以上繰り返し挿抜した後も，刃の欠けや先端刃角の変化は なく, 挿入荷重も変化しなかった.

\section{文献}

穴見貴幸，血液検体吸引装置，特開平 4-221741(1992).

朝倉俊成, 清野弘明, 野崎征支郎, 多種のインスリン自己注射専用針とインスリン製剂のゴム栓の組み合わせに よるコアリングの発生頻度，医療薬学会誌，Vol. 29, No. 4 (2003), pp. 457-463.

青柳誠司，泉隼人，MEMS 技術を援用したマイクロニードルの開発，精密工学会誌，Vol. 74，No. 11 (2008), pp. 1156-1159.

Farré, C., Velasco, J. and Ramón, F., Evaluation of the Olympus AU-510 analyser, Journal of Automatic Chemistry, Vol. 13, No. 5 (1991), pp. 217-220.

平野匡章, 森高通，分注装置及び分注方法，特開 2015-169623 (2015).

池田和由, 熊田美智男, 長谷川進一, 血液検査の迅速化とデータの正確性を追求した新自動分析装置 TBA-120FR, 東芝レビュー, Vol. 55, No. 9 (2000), pp. 66-69.

柏村孝義, 白鳥正樹, 于強, 国府田勲, 実験計画法,数理計画法を用いた構造最適化，日本機械学会論文集 $\mathrm{A}$ 編, Vol. 62, No. 601 (1996), pp. 218-223.

Kong, F., Yuan, L., Zheng, Y. F., and Chen, W., Automatic liquid handling for life science: a critical review of the current state of the art, Journal of Laboratory Automation, Vol. 17, No. 3 (2012), pp. 169-185. 
前川真人, 濱田悦子，これからの自動分析装置，医療機器学会誌，Vol. 80, No. 4 (2010), pp. 291-299.

小川宏治,佐藤敬，ノズルユニット, 特開 2010-25804 (2010).

左藤猛英, 血液生化学自動分析装置の開発, 精密工学会誌, Vol. 61, No. 1 (1995), pp. 59-64.

新村洋未, 小川鑛一, 國澤尚子, 針管, 針基および注射器筒先固定の条件下による注射針の反り, 日本人間工学会 第 53 回大会講演集, (2012), pp. 348-349.

竹腰久仁雄, 後藤學, 刃物の刃先先端のミクロ構造と切れ味劣化に関する研究，日本機械学会論文集 $\mathrm{C}$ 編, Vol. 70, No. 695 (2004), pp. 2155-2162.

Yancheng, W., Bruce, L. T., Roland, K. C. and Albert, J. S., The needle with lancet point: geometry for needle tip grinding and tissue insertion force, Journal of Manufacturing Science and Engineering, Vol. 135, No. 4 (2013), pp. 1-7.

吉村博仁, 片平雄, 渡邊英人, 山下泰樹, プリント配線板の微小径穴あけ加工におけるドリル回転数および工具摩 耗が切りくず排出性におよぼす影響, 日本機械学会論文集, Vol. 82, No. 834 (2016), DOI : 10.1299/transjsme.1500463.

\section{References}

Anami, T., Blood sample aspirator, Japanese patent disclosure H4-221741 (1992).

Asakura, T., Seino, H. and Nozaki, S., The occurrence of coring in multiple combinations of injection needles for insulin selfinjections and rubber stoppers, Japanese Society of Pharmaceutical Health Care and Sciences, Vol. 29, No. 4 (2003), pp. 457-463 (in Japanese).

Aoyagi, S. and Izumi, H., Development of a microneedle using MEMS technique, Journal of the International Society for Precision Engineering and Nanotechnology, Vol. 74, No. 11 (2008), pp. 1156-1159 (in Japanese).

Farré, C., Velasco, J. and Ramón, F., Evaluation of the Olympus AU-510 analyser, Journal of Automatic Chemistry, Vol. 13, No. 5 ( 1991), pp. 217-220.

Hirano, M. and Mori, T., Pipetter and pipetting method, Japanese patent disclosure 2015-169623 (2015).

Ikeda, K., Kumada M. and Hasegawa S., New TBA-120FR automated clinical analyzer pursuing faster measurement and high data accuracy, Toshiba Review, Vol. 55, No. 9 (2000), pp. 66-69 (in Japanese).

Kashiwamura, T., Shiratori, M., Yu, Q. and Kohda, I., Structural optimization using the design of experiments and mathematical programming, Transactions of the Japan Society of Mechanical Engineers, Series A, Vol. 62, No. 601 (1996), pp. 218-223 (in Japanese).

Kong, F., Yuan, L., Zheng, Y. F. and Chen, W., Automatic liquid handling for life science: a critical review of the current state of the art, Journal of Laboratory Automation, Vol. 17, No. 3 (2012), pp. 169-185.

Maekawa, M. and Hamada, E., Automated analyzer in the next generation, The Japanese Journal of Medical Instrumentation, Vol. 80, No. 4 (2010), pp. 291-299 (in Japanese).

Ogawa, K. and Sato, K., Nozzle unit, Japanese patent disclosure 2010-25804 (2010).

Sato, T., Development of automatic clinical chemistry analyzer, Journal of the International Societies for Precision Engineering and Nanotechnology, Vol. 61, No. 1 (1995), pp. 59-64 (in Japanese).

Shinmura, H., Ogawa, K. and Kunisawa, N., On bending displacements and forces of the syringe needles, Proceedings of the 53th Japan Ergonomics Society Conference (2012), pp. 348-349 (in Japanese).

Takekoshi, K. and Gotoh, M., Studies on micro-structure of a knife-edge and degradation of cutting performance, Transactions of the Japan Society of Mechanical Engineers, Series C, Vol. 70, No. 695 (2004), pp. $2155-2162$ (in Japanese).

Yancheng, W., Bruce, L. T., Roland, K. C. and Albert, J. S., The needle with lancet point: geometry for needle tip grinding and tissue insertion force, Journal of Manufacturing Science and Engineering, Vol. 135, No. 4 (2013), pp. 1-7.

Yoshimura, H., Katahira, Y., Watanabe, H. and Yamashita, T., Study on effect of drilling rotational speed and tool wear on chip evacuation of micro drilling of printed circuit board, Transactions of the JSME (in Japanese), Vol. 82, No. 834 (2016), DOI:10.1299/transjsme.15-00463. 